\title{
Effect of Calcium-Channel Blockade on the Aldosterone Response to Sodium Depletion and Potassium Loading in Man
}

\author{
Laurent Favre, Anne Riondel, and Michel B. Vallotton
}

Angiotensin II (Ang II) and potassium $\left(\mathrm{K}^{+}\right)$increase aldosterone (Aldo) production in vitro via $\mathrm{Ca}^{2+}$-dependent mechanisms. To determine the effects of $\mathrm{Ca}^{2+}$ antagonism in vivo, we examined the influence of nifedipine on the Aldo response to $\mathrm{Na}^{+}$depletion and $\mathrm{K}^{+}$loading in 11 healthy subjects. On the fifth day of a low-Na $/$ high- $\mathrm{K}^{+}$ $\operatorname{diet}\left(10 \mathrm{mmol} \mathrm{Na} / 100 \mathrm{mmol} \mathrm{K}{ }^{+}\right)$the subjects were randomly given either nifedipine $30 \mathrm{mg}$ po or placebo, and on the sixth day they received the alternative drug. $\mathrm{KCl}$ in $5 \%$ glucose was infused on days 5 and 6 from 10:00 to 12:00 AM (0.6 mmol $/ \mathrm{kg}$ over 2 hours). Dexamethasone was given to suppress adrenal corticotrophic hormone. Plasma renin activity (PRA) and plasma Aldo were determined every 20 minutes. Nifedipine induced a rise in heart rate at 60 minutes but did not change blood pressure. During $\mathrm{KCl} /$ glucose infusions, plasma glucose increased significantly, but plasma $\mathrm{K}^{+}$remained stable. PRA, but not baseline plasma Aldo, was stimulated by nifedipine. $\mathrm{KCl}$ provoked a significant and similar Aldo rise $(\mathrm{P}<.01)$ under placebo and nifedipine. Baseline Aldo/PRA ratio was reduced under nifedipine when compared to placebo $(\mathrm{P}<.01)$, whereas during $\mathrm{KCl}$ infusions this ratio was similarly elevated under placebo and nifedipine. We conclude that acute inhibition of slow $\mathrm{Ca}^{2+}$ channels does not interfere with $\mathrm{K}^{+}$-induced Aldo secretion in man, suggesting that adaptive mechanisms operate in vivo. Am J Hypertens 1988;1:245-248

KEY WORDS: Aldosterone response, calcium-channel blockade, nifedipine, potassium loading, sodium depletion.
$\mathrm{P}$ otassium $\left(\mathrm{K}^{+}\right)$and angiotensin II (Ang II) stimulate aldosterone (Aldo) production via calcium $\left(\mathrm{Ca}^{2+}\right)$-dependent mechanisms. Earlier studies using isolated adrenal glomerulosa cells have shown that inhibition of $\mathrm{Ca}^{2+}$ uptake blocked the steroidogenic response to both $\mathrm{K}^{+}$and Ang II. ${ }^{1-3}$ Recent work from this laboratory ${ }^{4}$ indicates that both Ang II and $\mathrm{K}^{+}$ increase intracellular $\mathrm{Ca}^{2+}\left(\left[\mathrm{Ca}^{2+}\right]_{\mathrm{i}}\right)$, but they do so by different mechanisms: Whereas $\mathrm{Ca}^{2+}$ antagonists can

From the Division of Endocrinology, University Hospital, Geneva, Switzerland.

This study was supported by a grant from the Swiss National Science Foundation No. 3. 914-0. 83 .

Address correspondence and reprint requests to Michael B. Vallotton, Division of Endocrinology, University Hospital, CH-1211 Geneva $4 /$ Switzerland. totally block the $\mathrm{K}^{+}$-induced $\left[\mathrm{Ca}^{2+}\right]_{\mathrm{i}}$ rise resulting from the opening of voltage-dependent $\mathrm{Ca}^{2+}$ channels and the subsequent Aldo production, they do not suppress the receptor-mediated $\left[\mathrm{Ca}^{2+}\right]_{\mathrm{i}}$ rise induced by Ang II, though they reduce the steroidogenesis slightly.

An inhibition of Aldo response to Ang II by acute administration of $\mathrm{Ca}^{2+}$-antagonists has been observed in human studies, ${ }^{5-7}$ but the effect of calcium antagonism on $\mathrm{K}^{+}$-induced Aldo stimulation has not yet been examined. The present study was therefore designed to compare the influence of nifedipine on the Aldo response to $\mathrm{Na}^{+}$depletion and $\mathrm{K}^{+}$loading in normal man. The experimental protocol we used raised a further working hypothesis regarding the mechanism by which $\mathrm{K}^{+}$-induced Aldo stimulation may involve insulin action. Our results suggest that intracellular $\mathrm{K}^{+}$may also influence Aldo secretion via a $\mathrm{Ca}^{2+}{ }_{-}$-independent mechanism. 


\section{METHODS}

Eleven healthy male subjects aged 23 to 27 years volunteered to participate in the study. They gave their informed consent to the experimental protocol, which has been approved by the Ethical Committee of the Department of Medicine.

The subjects were kept for 6 days on a strict low- $\mathrm{Na}^{+}$ $(15 \mathrm{mmol})$ and high- $\mathrm{K}^{+}(100 \mathrm{mmol})$ daily intake. On day 5 the subjects were randomly given either nifedipine (20 mg at 7:00 AM and 10 mg at 10:00 AM po) or a placebo. On day 6 they received the alternative drug. Dexamethasone $(1 \mathrm{mg})$ was taken at midnight on days 4 and 5 to suppress adrenal corticotrophic hormone (ACTH). On the fifth and the sixth days two similar $\mathrm{KCl}$-infusion tests were performed from 10:00 AM to 12:00 noon. After fasting overnight, the subjects remained supine from 7:00 AM to 12:00 noon. $\mathrm{KCl}$ diluted in $5 \%$ glucose $(50 \mathrm{mmol} \mathrm{KCl} / \mathrm{L})$ was infused over 2 hours $(0.6 \mathrm{mmol} / \mathrm{kg})$ through a large humeral vein.

Blood was drawn every 20 minutes during the $\mathrm{KCl}$ infusion for determination of plasma $\mathrm{Na}^{+}$and $\mathrm{K}^{+}$, plasma renin activity (PRA) and Aldo. Plasma glucose and plasma cortisol were measured at 60 and $120 \mathrm{~min}-$ utes. Plasma insulin was also determined in five subjects. Blood pressure and heart rate were checked regularly during the tests. Urinary $\mathrm{Na}^{+}$and $\mathrm{K}^{+}$were measured in 24-hour urine on the fifth day of the diet and in a urine spot on the sixth day.

$\mathrm{Na}^{+}$and $\mathrm{K}^{+}$were determined by flame photometry and plasma glucose by the glucose-oxydase method. PRA, plasma cortisol and insulin, and urinary Aldo were determined by radioimmunoassay (RIA). Plasma aldosterone was measured by RIA using a commercial kit (Coat-A-Count-Diagnostic Products Corp). The limit of detection was $1.5 \mathrm{ng} / 100 \mathrm{~mL}$, and the intra-assay coefficient of variation was $5.1 \%$.

Statistical analysis was performed by paired $t$ test, the subjects being their own controls. Results are expressed as the mean \pm SEM.

\section{RESULTS}

On the fifth day of low- $\mathrm{Na}^{+} /$high- $\mathrm{K}^{+}$diet, 24 -hour urinary excretion was $19.8 \pm 2.1 \mathrm{mmol}$ for $\mathrm{Na}^{+}$and $109.9 \pm 9.0 \mathrm{mmol}$ for $\mathrm{K}^{+}$. Urinary excretion of Aldo was $42.0 \pm 2.7 \mu \mathrm{g} / 24$ hours. In the sixth day urine spot $\mathrm{Na}^{+}$ was $12.0 \pm 2.2 \mathrm{mmol} / \mathrm{L}$ and $\mathrm{K}^{+}, 77.0 \pm 2.7 \mathrm{mmol} / \mathrm{L}$. Mean body weight was $68.7 \pm 3.3 \mathrm{~kg}$ on the fifth day and $68.5 \pm 3.2 \mathrm{~kg}$ on the sixth day (difference not significant [NS]).

Before $\mathrm{KCl}$ infusion blood pressure was $114 \pm 2$ / $69 \pm 2 \mathrm{~mm} \mathrm{Hg}$ on placebo and $115 \pm 2 / 69 \pm 1 \mathrm{~mm} \mathrm{Hg}$ on nifedipine (NS). Heart rate was $61 \pm 2$ and $66 \pm 3$ beats/minute, respectively (NS). At the end of the $\mathrm{KCl}$ infusion, blood pressure was $113 \pm 2 / 71 \pm 2 \mathrm{~mm} \mathrm{Hg}$ on placebo and $115 \pm 2 / 69 \pm 2 \mathrm{~mm} \mathrm{Hg}$ on nifedipine
(NS), and heart rate was $60 \pm 2$ and $65 \pm 3$ beats/minute, respectively (NS). However at 60 minutes, heart rate was significantly higher on nifedipine $(75 \pm 4)$ than on placebo $(60 \pm 2, P<.01)$.

The mean amount of $\mathrm{KCl}$ infused over 2 hours $(0.6 \mathrm{mmol} / \mathrm{kg})$ was $41.1 \pm 1.7 \mathrm{mmol}$. Despite this large load, plasma $\mathrm{K}^{+}$did not change significantly during the 2-hour infusion in either test (Figure 1). Plasma $\mathrm{Na}^{+}$ remained constant. The infused volume was $831 \pm$ $42 \mathrm{~mL}$ over 2 hours, providing a glucose load of $41.6 \pm$ $2.1 \mathrm{~g}$. On both placebo and nifedipine days, plasma glucose and plasma insulin increased significantly to a similar extent during $\mathrm{KCl}-5 \%$ glucose infusion with a peak at 60 minutes.

As shown in Figure 1, baseline PRA increased by $\mathrm{Na}^{+}$ depletion was further stimulated by nifedipine treatment, whereas plasma Aldo levels were similar on placebo and nifedipine days. Consequently the Aldo/PRA ratio was significantly higher on placebo $(5.6 \pm 0.6$ at time 0$)$ than on nifedipine $(3.9 \pm 0.5, P<.01)$. During $\mathrm{KCl}$ infusion, despite the absence of change in plasma $\mathrm{K}^{+}$concentration, there was a marked and highly significant rise in plasma Aldo, reaching a peak at 40 minutes on placebo $(P<.01 v s$ baseline $)$ and at 60 minutes on

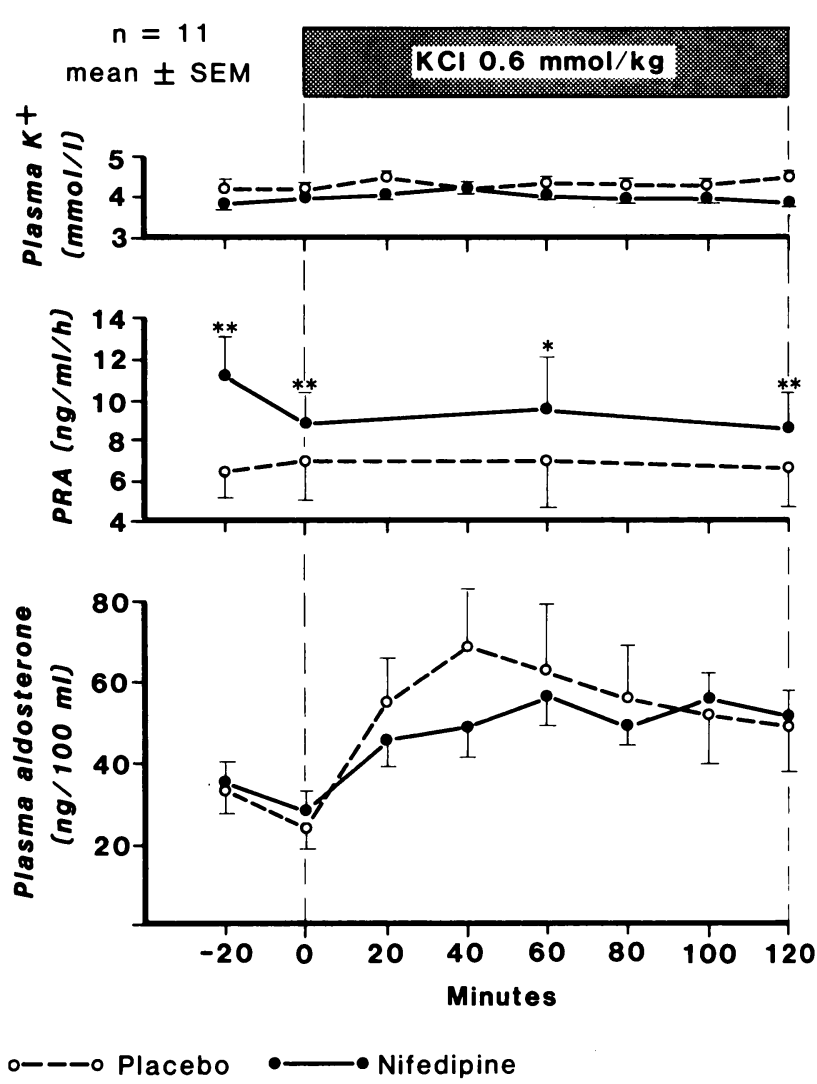

FIGURE 1. Effect of a 2-hour $\mathrm{KCl} \mathrm{IV}$ infusion $(0.6 \mathrm{mmol} / \mathrm{kg}$ in $5 \%$ glucose) on plasma potassium concentration, plasma renin activity and plasma aldosterone levels, in 11 healthy subjects during sodium restriction. See text for statistics. 
nifedipine $(P<.001$ vs baseline); peak values were not significantly different on placebo day $(41.2 \pm 10.0 \mathrm{ng} /$ $\mathrm{dL})$ and on nifedipine day $(34.8 \pm 3.8 \mathrm{ng} / \mathrm{dL})$. The Aldo/PRA ratio during $\mathrm{KCl}$ infusion was not significantly different on placebo and on nifedipine. Plasma cortisol levels remained suppressed during the tests $(1.7 \pm 0.4 \mu \mathrm{g} / \mathrm{dL}$ on placebo and $1.3 \pm 0.3$ on nifedipine/NS).

\section{DISCUSSION}

In vitro studies using adrenal glomerulosa cells indicate that although Ang II and $\mathrm{K}^{+}$both stimulate Aldo secretion by increasing $\left[\mathrm{Ca}^{2+}\right]_{\mathrm{i}}$, only the $\mathrm{K}^{+}$-mediated stimulation, acting through voltage-dependent $\mathrm{Ca}^{2+}$ channels, is specifically blocked by $\mathrm{Ca}^{2+}$ antagonists. ${ }^{4}$ Slow $\mathrm{Ca}^{2+}$ channel blockers can also decrease Ang II-induced Aldo production, but their effect is less marked than on $\mathrm{KCl}$-induced steroidogenesis. This lesser effect is a consequence of a lower basal intracellular $\mathrm{Ca}^{2+}$ concentration resulting from depletion of $\left[\mathrm{Ca}^{2+}\right]_{\mathrm{i}}$ stores by these drugs and preventing attainment of the critical threshold for triggering steroidogenesis. From these in vitro findings, it might therefore be inferred that acute inhibition of $\mathrm{Ca}^{2+}$ channels would interfere with $\mathrm{K}^{+}$-induced Aldo stimulation. In a sheep whose adrenal gland was transplanted to its neck, the local infusion of $\mathrm{Ca}^{2+}$ antagonists reversed the Aldo response to $\mathrm{K}^{+}$but did not affect Aldo secretion induced by $\mathrm{Na}^{+}$depletion. ${ }^{8,9}$

To assess the effect of $\mathrm{K}^{+}$on Aldo secretion, $\mathrm{KCl}$ was infused acutely after stimulation of the reninangiotensin system as in previous studies. ${ }^{10,11}$ It is known that in normal subjects a clear Aldo response to $\mathrm{K}^{+}$occurs only in the presence of high concentrations of Ang II. ${ }^{10}$ This fact emphasizes the important interdependence of Ang II and $\mathrm{K}^{+} .{ }^{12} \mathrm{KCl}$ was diluted in glucose to prevent a local venous toxic reaction. Although plasma $\mathrm{K}^{+}$did not rise during the $\mathrm{KCl}$-glucose infusion, there is strong evidence that Aldo stimulation was directly induced by $\mathrm{K}^{+}$, as previously reported. ${ }^{10}$ Glucose ingestion acutely lowers plasma concentrations of $\mathrm{K}^{+}$ and Aldo, ${ }^{11}$ whereas plasma Aldo levels rise during $\mathrm{KCl}$-glucose infusion, despite an unchanged $\mathrm{K}^{+}$plasma concentration, ${ }^{10}$ as confirmed in the present study. Whether $\mathrm{K}^{+}$enters the cell in order to stimulate steroidogenesis is still conjectural, as opposite conclusions have been drawn from in vitro or in vivo studies using direct or indirect estimation of intracellular $\mathrm{K}^{+}$content. ${ }^{10,11,13}$ Insulin stimulates $\mathrm{K}^{+}$cellular uptake by the liver and muscle tissues, ${ }^{14}$ but it is not known whether tissues like the adrenal cortex are also involved. These findings suggest that either membrane depolarization occurs without any apparent change in $\mathrm{K}^{+}$extracellular concentration (which is unlikely, as high concentration is required in vitro to depolarize glomerulosa cells ${ }^{4}$ ), or that the signal may result from transmembrane $\mathrm{K}^{+}$ fluxes leading to a higher intracellular $\mathrm{K}^{+}$concentration.
If these processes are mediated by the $\mathrm{Ca}^{2+}$ fluxes demonstrated in vitro, ${ }^{4}$ they would also be blocked in vivo by $\mathrm{Ca}^{2+}$ antagonists. This was not the case in this study because, contrary to our expectation, nifedipine was unable to prevent the $\mathrm{K}^{+}$-induced rise in Aldo concentration, the peak value of which during $\mathrm{KCl}$ infusion being similar on placebo and nifedipine treatment. Similar results showing no interference by nifedipine with Aldo secretion have been reported recently in hypertensive patients given an acute $\mathrm{KCl}$ infusion. ${ }^{15}$ Our findings indicate that the mechanism of $\mathrm{K}^{+}$-induced Aldo secretion under these particular in vivo circumstances differs from that observed in vitro in isolated cells. In this study, as in an earlier one ${ }^{16}$ insulin response to hyperglycemia was not altered by nifedipine. The two $\mathrm{KCl}$ infusions were therefore comparable in terms of glucose load and insulin secretion. Insulin alone can influence plasma $\mathrm{K}^{+}$ concentration, baseline plasma Aldo levels and its response to Ang II in various ways. ${ }^{17}$

In the present in vivo human study under low salt intake, nifedipine reduced the Aldo/PRA ratio but did not alter $\mathrm{K}^{+}$-induced Aldo secretion. Renin secretion was clearly stimulated as a result of a combined effect of $\mathrm{Na}^{+}$depletion and acute inhibition of slow $\mathrm{Ca}^{2+}$ channels, and as previously reported, ${ }^{18}$ it was not modified by $\mathrm{KCl}$ administration. The high basal plasma concentration of Aldo induced by Ang II stimulation was similar on nifedipine and placebo. Despite the known higher sensitivity of adrenal cells after $\mathrm{Na}^{+}$depletion, ${ }^{19}$ no further increase in Aldo secretion could be obtained in response to the acute renin rise under nifedipine treatment. The finding of a lower Aldo/PRA ratio during nifedipine treatment, previously reported in hypertensive patients, ${ }^{20}$ is compatible with the acute inhibitory effect of nifedipine on steroidogenesis during Ang II infusion in man. ${ }^{5-7}$ Another unrelated $\mathrm{Ca}^{2+}$ antagonist, verapamil, did inhibit Aldo response to Ang II, but only when given chronically. ${ }^{21}$ During sodium restriction in normal subjects nifedipine and diltiazem reduced the sensitivity of Aldo secretion to Ang II. ${ }^{7}$

As nifedipine has been shown to increase apparent liver blood flow in normal subjects, ${ }^{22}$ an alteration of Aldo metabolic clearance rate is to be considered so that changes in Aldo plasma concentrations may not parallel changes in Aldo secretion. To exclude any contribution of another $\mathrm{Ca}^{2+}$-independent adrenal trophic factor, ACTH was constantly suppressed by dexamethasone during the two test days. In fact Guthrie et $\mathrm{al}^{21}$ have reported that verapamil does not alter the Aldo response to ACTH. Nifedipine, known to bind with high affinity and specificity to the voltage-dependent $\mathrm{Ca}^{2+}$ channel, ${ }^{23}$ was administered shortly before $\mathrm{KCl}$ infusion. It may be inferred from pharmacokinetic data that the dose selected would result in plasma concentrations in the same micromolar range as the in vitro studies, although individual bioavailability may vary. ${ }^{24}$ The PRA 
rise obtained in every subject indicates that effective drug levels were achieved. Blood pressure was not influenced, as would be expected in normotensive subjects. ${ }^{25}$

In summary, acute blockade of slow $\mathrm{Ca}^{2+}$-channels does not interfere with $\mathrm{K}^{+}$-induced Aldo secretion but reduces the Aldo/PRA ratio. These findings suggest some inhibition of the Ang 2-induced Aldo secretion. The discrepancy with in vitro findings indicates that adaptive mechanisms operate in vivo allowing the maintenance of Aldo secretion in normal man. Finally, these results support the existence of a role for intracellular $\mathrm{K}^{+}$in stimulating Aldo secretion.

\section{ACKNOWLEDGMENTS}

The authors are grateful to Dr L. Vadas (Central Laboratory of Clinical Chemistry) for insulin determinations, to Mrs L. Bockhorn, M. Lopez, W. Dimeck and C. Chauffat-Rabère for their excellent technical assistance, and to Mrs M. Aebischer for her secretarial help.

\section{REFERENCES}

1. Fakunding JL, Catt KJ: Dependency of aldosterone stimulation in adrenal glomerulosa cells on calcium uptake: Effects of lanthanum and verapamil. Endocrinology 1980;107:1345.

2. Schiffrin EL, Lis M, Gutkowska J, Genest J: Role of $\mathrm{Ca}^{++}$ in response of adrenal glomerulosa cells to angiotensin II, ACTH, $\mathrm{K}^{+}$and ouabain. Am J Physiol 1981;241:E42.

3. Foster R, Lobo MV, Rasmussen H, Marusic ET: Calcium: Its role in the mechanism of action of angiotensin II and potassium in aldosterone production. Endocrinology 1981;109:2196.

4. Capponi AM, Lew PD, Vallotton MB: Correlation between cytosolic free $\mathrm{Ca}^{2+}$ and aldosterone production in bovine adrenal glomerular cells. J Biol Chem 1984;259:8863.

5. Millar JA, McLean K, Reid JL: Calcium antagonists decrease adrenal and vascular responsiveness to angiotensin II in normal man. Clin Sci 1981;61:65s.

6. Vierhapper $H$, Waldhäusl W: Reduced pressor effect of angiotensin II and of noradrenaline in normal man following the oral administration of the calcium-antagonist nifedipine. Eur J Clin Invest 1982;12:263.

7. Anderson GH Jr, Howland T, Domschek R, Streeten DHP: Effect of sodium balance and calcium channelblocking drugs on plasma aldosterone responses to infusion of angiotensin II in normal subjects and patients with essential hypertension. J Clin Endocrinol Metab 1986;63:1126.

8. Johnson EIM, McDougall JG, Coghlan JP, et al: Potassium stimulation of aldosterone secretion in vivo is reversed by nisoldipine, a calcium transport antagonist. Endocrinology 1984;114:1466.

9. Johnson EIM, McDougall JG, Coghlan JP, et al: Ca antagonists do not alter aldosterone secretion during established Na depletion. Am J Physiol 1985;248:E676.
10. Birkhäuser M, Gaillard R, Riondel AM, et al: Effect of volume expansion by hyperosmolar and hyperoncotic solutions under constant infusion of angiotensin II on plasma aldosterone in man and its counterbalance by potassium administration. Europ J Clin Invest 1973;3:307.

11. Himathongkam T, Dluhy RG, Williams GH: Potassiumaldosterone-renin interrelationships. J Clin Endocrinol Metab 1975;41:153.

12. Pratt JH: Role of angiotensin II in potassium-mediated stimulation of aldosterone secretion in the dog. J Clin Invest 1982;70:667.

13. Decorzant C, Riondel AM, Philippe MJ, et al: Detection of $\mathrm{Na}^{+}$and $\mathrm{K}^{+}$in the rat adrenal cortex with the electron microprobe. Clin Sci 1977;53:423.

14. DeFronzo RA, Felig P, Ferrannini E, Wahren J: Effect of graded doses of insulin on splanchnic and peripheral potassium metabolism in man. Am J Physiol 1980;238:E421.

15. Leonetti G, Terzoli L, Zanchetti A: Calcium-antagonist and responsiveness of the adrenal gland to aldosterone releasing stimuli in hypertensive patients. J Hypertens 1987;5(Suppl 4):S119-122.

16. Donnelly T, Harrower ADB: Effect of nifedipine on glucose tolerance and insulin secretion in diabetic and non diabetic patients. Curr Med Res Opin 1980;6:690.

17. Vierhapper H: Effect of exogenous insulin on blood pressure regulation in healthy and diabetic subjects. $\mathrm{Hy}$ pertension 1985;7(suppl 2):49.

18. Scholer D, Birkhäuser M, Peytremann A, et al: Response of plasma aldosterone to angiotensin II, ACTH and potassium in man. Acta Endocrinol 1973;72:293.

19. Hollenberg NK, Chenitz WR, Adams DF, Williams GH: Reciprocal influence of salt intake on adrenal glomerulosa and renal vascular responses to angiotensin II in normal man. J Clin Invest 1974;54:34.

20. Lederballe Pedersen O, Mikkelsen E, et al: Effect of nifedipine on plasma renin, aldosterone, and catecholamines in arterial hypertension. Eur J Clin Pharmacol 1979;15:235.

21. Guthrie GP Jr, McAllister RG Jr, Kotchen TA: Effects of intravenous and oral verapamil upon pressor and adrenal steroidogenic responses in normal man. J Clin Endocrinol Metab 1983;57:339.

22. Feely J: Nifedipine increases and glyceryl trinitrate decreases apparent liver blood flow in normal subjects. $\mathrm{Br}]$ Clin Pharmac 1984; 17:83.

23. Glossmann H, Ferry DR, Lubbecke F, et al: Calcium channels: Directs identification with radioligand binding studies. Trends Pharmacol Sci 1982;3:431.

24. Raemsch KD, Sommer J: Pharmacokinetics and metabolism of nifedipine. Hypertension 1983;5(suppl 2):11.

25. Aoki K, Kondo S, Mochizuki A, et al: Anti-hypertensive effect of cardiovascular $\mathrm{Ca}^{2+}$-antagonist in hypertensive patients in the absence and presence of beta-adrenergic blockade. Am Heart J 1978;96:218. 